\title{
Stakeholders' Appraisal of Public Secondary Schools' Communication in the South West Region of Cameroon
}

\author{
Nengieh Lizzie Wantchami* \\ Department of Journalism and Mass Communication, Department of Educational Foundations and \\ Administration, University of Buea, Cameroon
}

*Corresponding Author: Nengieh Lizzie Wantchami, Department of Journalism and Mass Communication, Department of Educational Foundations and Administration, University of Buea, Cameroon

\begin{abstract}
This study seeks to examine public secondary schools (PSS) communication in South West region of Cameroon by examining their relationship with the media, their stakeholders' satisfaction with their means of communication and their accountability to their stakeholders. It made use of the concurrent procedures of mixed methods in which the researcher converge quantitative and qualitative data in order to provide a comprehensive analysis of the research problem. 12 public secondary schools were randomly selected from six divisions of the SW Region of Cameroon, 2 from each division representing the rural/urban setting. 20 school administrators were interviewed using open-ended questionnaires. 48 teachers, 55 parents and 1094students were also interviewed for the study. Findings reveal a weak relationship between public secondary schools and the media and meetings are the most use form of communication between PSS and students (98.5\%), teachers (100\%) and parents (87.3\%). However, e-mail is considered the most comfortable means of communication by teachers $(81.3 \%)$ while students $(68.6 \%)$ and parents (43.6\%) meetings. Study further reveal that PSS are not accountable to teachers and students but are accountable to parents. Therefore, PSS in SW region of Cameroon need to improve not only their communication means but their accountability to stakeholders especially the internal stakeholders.
\end{abstract}

Keywords: Stakeholders, Communication, Education, Administration, Public Secondary School Cameroon

\section{INTRODUCTION}

Communication has been identified as a serious problem to the advancement of the image of public schools in Cameroon. The development of education rests essentially on the improvement of its supply, demand and, notably, good management [1] Owing to the fact that information is either absent or insufficient since the information system is not organised, public finance archives are not stored and there is no existing regulation obliging the different interveners to vehicle information [2] public secondary schools in Cameroon suffer tremendously in terms of school management which infringes on the activities and projects carried out in the school, with due consequence on their image.

The organisational chart of public secondary schools in Cameroon explains the gap in communication between the schools' stakeholders and the school which has an adverse effect on its image. The communications or public relations office is absent in the organisational chart of public secondary schools, which underrates communication as a major element in binding the three major systems of a school; namely, the community system, the management system and the technical system. According to [3], this kind of bureaucratic organisational approach leaves little room for staff participation in policy decisions and does not encourage free flow of communication. He adds that it places excessive emphasis on the chain of command which increases the social distance between superiors and subordinates [3,4] and the internal and external stakeholders of the school.

At the core of bureaucracy is the institutionalisation of power [4]. It takes away power from foremen and vests it in government policy and rules. It is no longer your immediate supervisor telling you what to do and why; it is the government $[3,4]$. The immediate supervisor is merely enforcing the rules, not making them up. Bureaucratic control systematically rewards certain behaviours that support the control system itself. That is, it seeks to mould the behaviour of the worker.

[5] asserts that the deeper concern with the totalitarian characteristics of bureaucratic control was, and is, the seemingly growing dissatisfaction of workers losing their autonomy as rules came to govern 
everything from the direction of work, evaluation of work, reward and punishment of work and even the workers' behaviour at work.

This situation is preoccupying in the Cameroonian setting as education analysts in Cameroon have stated that some laws, for example, part II, section 11 of law No 004/98 under the Cameroon education system, do not have specific criteria or performance indicators, hence their implementation and evaluation by school administrators become difficult, leaving room for unsatisfied workers within the system [6, p.53]. Furthermore, schools are run arbitrarily, guided by arêtes otherwise circulars which differ and/or are changed with the change of ministers. Without defined rules and regulations for operation, school culture is rather defined by individuals who themselves do not understand the principles of operation, leaving room for an undefined identity which is basically projected in the image of schools leading us to a query about the desired identity of public secondary schools following the school administrator's perspective. This bureaucratic constrains are as a result of administrative dependence. According to [7] and [8] they are dependent on tax-supported government agencies, administratively dependent and are relatively cheap in terms of fees and therefore harness larger populations of students.

[9] assert that from reports of disappointing academic performance to shockingly violent acts by a few students, schools have had an overabundance of negative publicity in the past several years. They lament that some of these stories have been legitimate, fair, and carefully reported; others unfair, poorly done, and sensationalised. Nevertheless, schools are left to deal with the resulting images and impressions, justified or not [9].

This is the case with most secondary schools in Cameroon, be it public or private. The public schools are mostly left to wonder about stories reported about them by the media and the rumours that circulate still about them. Grievous incidents such as the murder of a young man by students of Baptist High school, Buea, suspected of being a thief [10]; the stabbing to death of a Lower Six Arts student of St. Joseph's College, Sasse, Buea, by a Form Five student of the same college [11]; the Principal of Government Bilingual High School (GBHS) Nkambe being slammed an 11-year jail term by the Fako High Court for child trafficking [12; and positive events like a 13-year-old student of GBHS Etoug-Egbe, Yaounde winning the prize of the best speller in the annual edition of the spelling competition [13] need to be communicated through proper communication channels to boost the image and clarify the doubts of the different stakeholders involved with the school.

[14] stipulates that poor communication accounts for over one-third of the problems of any social organisation such as education. He notes that it is an axiom that the adequacy and appropriateness of information and its communication determines to a great extent the way people perceive and react in any human organisation. The process of communication in any organisation involves four major elements (sender, message, medium and receiver), each of which is crucial to the life of the organisation and cannot operate in isolation. [14] clarifies this point by stating that both the channel (medium) and feedback are aspects of the medium which is created by the environment of the sender and the receiver. He further cautions that every administrator must watch his/her language of communication because it can cause deficiency between the sender and the receiver. The receiver often translates the message according to his/her thoughts, desires or attitudes; hence communication processes must be thoroughly planned, prepared and couched in simple, easily understood terminology[14]. Public secondary schools in Cameroon can improve on the quality of school infrastructure, school discipline, curriculum, and teaching standard if they engage with their stakeholders through strategic communication. By becoming more accountable, by relating and creating linkages and partnerships with the school community and the alumni, public secondary schools could raise funds for the local school projects; publicising the core components of the school will also promote their unique identity which definitely will reflect their image. This study therefore seeks to understand how public secondary schools in the South West region of Cameroon communicate with their stakeholders by examining to the following research questions:

- What is the relationship between PSS in the SW region and the media?

- What are the means of communication used by PSS in the SW region of Cameroon?

- How satisfied are PSS stakeholders' with the varied means of communication used by PSS? 
- How accountable are PSS to their stakeholders?

\section{LITERATURE REVIEW}

\subsection{School Communication and Stakeholders}

This study makes use of the systems/stakeholder's theory as well as the [15] corporate identity/corporate image model. These different theories and models share the premise that organisations must concern themselves with their environment to survive [16] and the way organisations present themselves to its stakeholders (corporate identity) may influence the stakeholder's perception of the organisation (corporate image) [15, 17].

A stakeholder is considered an individual or a group of individuals in the community who have a vested interest in what is occurring for overall success. Stakeholders can be anyone actively involved in welfare and success of the school. Stakeholders are key to the success of the students, school, board, or any other school entity. Therefore, stakeholders consist of students, parents, school staff, district staff, school board, taxpayers, business community, and other community members. The internal and external stakeholders have different roles, but are both key to long-term success of the school. The internal stakeholders are those who work directly within the school. The external stakeholders are outside the school and generally have a vested interest, but are not affiliated with school [18].

Stanford Research Institute (SRI) defines stakeholders as those groups without whose support the organisation would cease to exist [19]. Theoretically, the widespread adoption of the stakeholder perspective in business marks a move away from the neo-classical economic theory of organisations to a socio-economic theory within which the stakeholders' perspective is embedded. The neoclassical economic theory suggests that the purpose of organisation is to make profits in their accountability to themselves and shareholders and that only by doing so can business contribute to wealth for itself and for the society at large [20]. The socio-economic or stakeholder theory suggests, in contrast, that the notion of accountability in fact looms larger: to other groups outside shareholders who are more important for the continuity of the organisation and the welfare of the society [21]. This study appeals to the socio-economic dimension of the stakeholder theory

The stakeholder model assumes that all persons or groups with legitimate interests in an organisation do so to obtain benefits and there is in principle no priority for one set of interests and benefits over another. The theory further assumes that all those groups that have legitimate stakes in the organisation, whether purely financial, market-based or otherwise, are recognised, and the relationship is not linear but one of interdependence. The stakeholder management model recognises the mutual dependencies between organisations and various stakeholding groups- groups that are themselves affected by the operations of the organisation but can equally affect the organisation, its operations and performance [22].

[22] further asserts that the interests of stakeholders are intricately varied and at times at odds with one another. Hence, it is essential that an organisation such as a school provides each stakeholder group with specific information and builds a strong reputation across exchanges with all these stakeholders. In order to do so, [23] recommends that communication practitioners start with identifying and analysing the organisation's stakeholders and their influence and interest in the organisation. In this way, [23] explains that they have a clearer idea of what the information needs of stakeholders are, what specific positions they have on an issue or in relation to a corporate activity, and what kind of communication strategy needs to be used to maintain support or counter opposition. [14] asserts that education is one of the organisations whose functions depend on effective communication among those concerned. He reiterates that apart from the need of effective communication and coordination in the management structure, the basic function of education relies almost entirely on communication among teachers and students and coordination among various organisational structures and levels. However, he laments that no element of administration is taken as much for granted, mistaken, misused and poorly understood as the element of communication.

Public schools need to realise that building a positive relationship with their stakeholders is a leeway to building a positive image for their schools. Relationship building entails building a conducive climate for employees who transcend such climates to the external environment. This idea is 
supported by many public relations scholars [24, 25, 26, 27] who acknowledge that among the different strategic publics that organisations are facing, employees are no doubt the ones with whom organisations have the closest connection. Employees are spokespersons and ambassadors who represent organisations in the face of strategic publics [26]. With the aid of social media, employees are becoming empowered, constructing their own information networks and dialogues. With the ubiquity of information, people talk about organisations both inside and outside [28]. Effective employee communication, which nurtures favourable employee attitudes, contributes not only to job satisfaction, organisational performance, and achievement of organisational goals [29, 30, 27, 31], but also helps protect organisational reputation in a turbulent environment because employees are viewed as credible sources to external stakeholders [24, 27, 32].

Communication could be seen as a system binder, the reasons being that, on the one hand, communication strives to integrate all other subsystems in a way that creates internal stability of the social system. On the other hand, communication is seen as a link with the environment which permits the system to cope with changes in environmental forces. According to [16], communication acts not only as a stimulus for action, but is also a control in coordinating mechanisms, in a way of tying decision centres in the system into a synchronised whole. From this standpoint, it is useful to see a system in terms of a communication network. For example, one could visualise a decision as a communication process. Decisions only occur when people receive some kind of communication that might have been combined from different sources. By transferring the results to a subsystem, there is communication. When this is treated as a whole, the different subsystems of communication will again form a communication network of the system. This network acts as a path through which information about one system is transmitted to the subsystem [33].

In the case of secondary schools, the external stakeholders either give the system opportunities or impose constraints on it. Therefore, there should be a mechanism put in place when the organisation perceives an external change [33]. Such mechanism will enable the organisation (system) to identify environmental changes and deal with them appropriately and adequately. [16] refers to such processes as adaptive mechanisms and adds that the efficiency of such mechanisms will depend on the competence of the communication system which serves as a sensory element, gathering information about the environment and feeding it into the system to be used by the control centre for decisionmaking purposes. That is public relations (PR) activities such as environmental scanning which brings information into the system and external communications which send information into the organisational environment serve as feedback functions that help the client systems interpret their environments in order to maintain homeostasis [34]. Therefore, if communication strategies used do not succeed to identify and gather information about environmental changes, some vital decisions would not be made and even when such information is identified and gathered but is not transmitted swiftly and correctly to the control centre, the decisions will not be timely and may even turn out to be inappropriate. This therefore means that the tendency of any organisation to witness an improved image would largely depend on the efficiency of its communication systems.

\subsection{Corporate Communication Means}

[35] define corporate communication as a term that encompasses all the ways in which an organisation communicates with different parties. [17, p.26] employs similar definitions of corporate communication as "an instrument of management by means of which all consciously used forms of internal and external communication are harmonised as effectively and efficiently as possible, so as to create a favourable basis for relationships with groups upon which the organisation is dependent". Corporate communication can be both controlled and uncontrolled in its nature. Thus, all the messages emanating out of the organisation, all that it produces, and all the activities it takes part in shape the perceptions the stakeholders have of the organisation. What this means is that everything the organisation does has an effect on how it is perceived, whether it be positively or negatively. Therefore, it is imperative for every organisation to recognise the importance of controlling communication in the same vein as controlling other resources [35, p. 49-71]. [36] defines administration as the means by which formal goals are achieved through cooperative human efforts. The basic functions and roles of the management cannot be conducted without communication. Planning, organising, coordinating, budgeting, monitoring and other related activities cannot be coordinated, harnessed and their goals achieved without communication. 
[37] argues that the consideration regarding the term 'Public Relations' in schools is due to the lack of expertise and lack of specialist training. He explained that it had been ignored in the past as little attention had been given to it and still it is considered that this skill can easily and cheaply be acquired by school managers [38]. [39] quoted a principal who said that her "Aim is to describe what is going on inside the school in order to let parents choose to use reliable information instead of gossip". The purpose of publicity and public relations, from an educational institute's point of view, is to keep the public in touch with the institution [40]. Schools greatly emphasise public relations in order to obtain media exposure and publicity instead of paid advertisements. Schools' marketing policies largely depend on press coverage of their activities that will ultimately promote their brand name and image. Thus, they may be in a position to attract prospective students [41]. [42] said that most English principals advertise their school's events in the press to position their school in the local community. [43] indicated that many schools, through their good work publicized by the press, make good relationships with the local media. [44] said that most dynamic school principals considered the press as an environmental management strategy. They recognised the fact that good public relations have strong influences on parental judgments of local schools.

[14] defines communication as a process of sending and receiving messages, information, ideas, instructions or intentions and is therefore necessary for linking together the various departments, programmes, activities and services in the organisation. According to [14], communication in schools encompasses all forms of interpersonal contacts, written and unwritten, arising from the organisational flow chart purported to: 1) maintain association with the community in which the institution stands, 2) show concern for the development of each child who is at the centre of the educational process, 3) facilitate personnel efficiency and effectiveness, 4) enhance the daily school routines and programmes, 5) succour the utilisation of the available school resources, budget and accounting procedures, 6) update the evaluation of school educational programmes, and 7) solve the individual and group problems of school personnel and promote staff development

[45, p16] considers communication as "the interchange of facts, thoughts, value judgements and opinions that may take many forms, such as face-to-face conversations, telephone calls, informal and formal meetings, conferences, memoranda, letters, report tabulations, VDU (Video Display Unit) transmission and so on." He underlines that whatever the process, good communication results when the sender and receiver are in accord over the meaning of a particular message.

Secondary schools in Cameroon should realise that using the appropriate message and medium of communication is a tool in enhancing the image of a school and in winning support for its projects. The medium for communicating with the different stakeholders of the schools may vary. [46] proposed various venues through which the school may reach its publics, including school assembly, bulletin board, letters and memoranda, staff meetings, school rules and regulations, and PTA meetings. [47] further urges public secondary schools to create multipurpose viewbooks and other promotional materials such as brochures and fliers that could be attached as appendices and sent out to local businesses for annual fund solicitation and grant applications. They could also be used as appeal to parents who have just moved into the region, enlighten people about school programmes, location, virtues of the school, stellar athletic teams, quality of teachers and staff. [47] concludes that viewbooks and school websites can serve as a school's silent weapon - as long as they are of professional quality, honest and informative. According to [48], school leaders on their side display the responsibility of communication when they set up and preside over informal, biweekly, afterschool discussion sessions at which teachers can discuss their concerns. The school leader demonstrates the responsibility of communication when he/she initiates a monthly newsletter distribution to all faculty members, parents, and community leaders describing significant decisions he/she has made or is considering about the institution.

However, the acceptance of a digitalised world, which is evident in Cameroon secondary schools today, through the teaching of information technology, calls for the need for schools to adapt to the ever-changing situation by creating their own websites which have the capacity to communicate with the internal and external stakeholders. ICTs have remained the backbone through which education is enhanced, but very few public secondary schools in Cameroon have a multimedia centre, not to mention accessible internet connections within their school campuses. [49] alleges that after the introduction of ICTs into education by President Paul Biya in 2001, very few multimedia resource 
centres (MRCs) have been created in public secondary schools. He lamented that these projects rely mainly on external funding, thus calling their sustainability into question. Moreover, public secondary schools have poor purchasing power, and no budget has been allotted to support ICT-related activities in schools. Most computers used in schools are donations [49]. [50] assert that people have to access knowledge via ICT to keep pace with the latest developments. ICT can be used to remove communication barriers such as that of space and time [51] and allow for the creation of digital resources like digital libraries where the students, teachers and professionals can access research materials and course materials from any place at any time [52]. Such facilities allow the networking of academics and researchers and hence sharing of scholarly materials [49] which helps increase the school's visibility and impacts its image. Public schools need to canvass for sponsorship and donations of ICT tools by creating partners in order to embrace the benefits of this technological innovation. [27] carried out an open interview of 147 employees of a multi-campus university view of information flow from top administration and found that e-mail and website were interesting mentioned as preferred sources to receive information from school administration. They explained that although e-mail is efficient for information exchange, the preference for communication among all groups of employees was face to face interpersonal dialogic interactions. Meetings despite acknowledged as time-consuming is valued as a channel for feedback and provides face time with top managers while electronic channels if used thoughtfully can flattened the traditional hierarchical structure of internal communication and give employees at all levels of the school the sense of hearing things first hand from the top [27]. [18] cited different means which schools communicate with their stakeholders in the United States including parent-teacher conferences, open houses, and report cards, curriculum nights, home visits, newsletters, orientations, web pages, email blast. However, [18] explains that some schools are often heavily influenced by social media forms such Facebook, Twitter, and Instagram which is hardly the case in the Cameroon setting. For stakeholders, two-way communication helps to strengthen collaborative partnerships. These partnerships can eventually be very beneficial for student academic success. The main emphasis is placed on providing relevant timely information to external stakeholders [18].

\section{MATERIAL AND MeTHOdS}

\subsection{Research Design}

This research contains a mixed method design; a mix or combination of qualitative and quantitative research techniques, methods and concepts within a single study $[53,54,55]$. A mixed method design can be highly valuable in comparison to a single method as it can address complex research questions and enables researchers to gather a richer and stronger set of evidence [55]. This research makes use of the concurrent procedures of mixed methods in which the researcher converges quantitative and qualitative data in order to provide a comprehensive analysis of the research problem. In this design, the investigator collects both forms of data at the same time during the study and then integrates the information in the interpretation of the overall results. Also, the researcher nests one form of data within another and larger data collection procedure in order to analyse different questions or levels of units in an organisation [54]. Data was gathered quantitatively in the form of a cross-sectional survey using questionnaires, and qualitatively in the form of an open-ended questionnaire. According to [56], surveys include cross-sectional and longitudinal studies using questionnaires or structured interviews for data collection, with the intent of generalising from a sample to a population.

\subsection{Sampling Procedure and Sample Size}

Public secondary schools under the general section in the South West Region were stratified into groups according to divisions (6 groups). Each group was then divided into two according to rural and urban settings (12 groups). Urban and rural schools were recognised in terms of their development and age. A simple random sampling method was then used in selecting 12 schools using the lottery method from the 12 groups; 6 rural and 6 urban schools, one per category from each division. Based on the lottery method, the names of rural and urban schools from each division were written on paper and folded. The folded papers were then put in 12 boxes representing the 12 groups and well stirred. A tag was then drawn from each box until we arrived at 6 rural and 6 urban schools according to division as represented in table 2. The gender breakdown was also based on proportion. Students were randomly selected from Forms, 4, 5 to Lower Sixth and Upper Sixth classes of each school. 
These classes were purposively sampled owing to their duration in that school which gives them knowledge about the activities of the school.

The researcher conveniently sampled 2 school administrators, 5 teachers and 5 parents per school within the 6 divisions (2x12schools; $5 \times 12$ schools; $10 \times 12$ schools) giving a sample size of 24 school administrators, 60 teachers and 60 parents for the study. The sample size for students was estimated using sample calculation for one proportion with the support of Epilnfo 6.04d [57] as explained by [58].

$\mathrm{n}=\frac{N Z^{2} P(1-P)}{d^{2}(N-1)+Z^{2} P(1-P)}$

Where $\mathrm{N}=$ total population, $\mathrm{Z}=\mathrm{Z}$ value corresponding to the confidence level, $\mathrm{d}=$ absolute precision, $\mathrm{P}=$ expected proportion in the population, $\mathrm{n}$ effective $=\mathrm{n} *$ design effect. The prospected prevalence is $50 \%$ for an optimal sample size. The precision considered is 5\%, a design effect (marginal error) of 1 given that simple random sampling was used to select the schools. For a total study population of public grammar secondary students in the South West Region of 49115 (Regional Delegation of the South West, 2012/2013), the sample size at 95\% CI estimated as explained above is 1162 . This sample size is shared proportionately to size, to the divisions and schools.

Table1. Distribution of sample by Division

\begin{tabular}{|c|c|c|}
\hline Division & Total number of students & Sample size \\
\hline Fako & 7536 & 178 \\
\hline Manyu & 9578 & 227 \\
\hline Kupe Manengouba & 6831 & 162 \\
\hline Ndian & 520 & 12 \\
\hline Lebialem & 6573 & 156 \\
\hline Meme & 18077 & 428 \\
\hline Total & 49115 & 1162 \\
\hline
\end{tabular}

At the end of the data collection procedure, a code guide was designed and questionnaires were coded by 6 coders in order to ensure inter-coder and intra-coder reliability. 1094 students, 20 school administrators, 48 teachers and 55 parents completed the survey. Data were made essentially categorical variables and they were analysed using frequencies and proportions and Multiple Response Analysis to aggregate responses within conceptual components. To ensure the validity of the tools, the researchers submitted the questionnaires to research experts. This involved assessing the consistency of the questionnaire to the research objectives. Reliability of research instrument was assured by carrying a pilots study as well as applying Cronbach Alpha reliability analysis. Chi-Square test was used to compare proportions for significant difference and to measure the association between categorical variables. The collected data were analysed quantitatively using Statistical Package for Social Sciences (SPSS version 21.0) and qualitatively using thematic analysis.

\section{RESULTS AND DISCUSSION}

\subsection{Public Secondary Schools relation with the Media}

\subsubsection{Journalists' Attitude towards Public Secondary Schools}

In overall, $58.3 \%$ of the journalists had negative convictions/beliefs toward public secondary schools, with $26.9 \%$ who neither agreed nor disagreed (neutral). However, just 33.3\% (3) of the journalists agreed that their attitude toward public secondary schools is positive, followed by $22.2 \%$ (2) of equal weight who agreed that the management of public secondary schools is welcoming and prefer to relate with public secondary schools to relating with private secondary schools. In the same trend, just $11.1 \%$ (1) of the journalists judged the image of public secondary schools to be very good.

Journalists for the majority had a negative impression of public secondary schools, with a proportion of $58.3 \%$ as against $22.2 \%$ for those who had a positive impression and this difference was statistically significant $(\chi 2$-test: $\chi 2=11.80 ; \mathrm{df}=2 ; \mathrm{P}=0.003)$ indicating that journalists have a weak relationship with public secondary schools. 
Table2. Journalists' attitude towards public secondary schools

\begin{tabular}{|l|c|c|l|l|}
\hline \multicolumn{1}{|c|}{ Items } & \multicolumn{1}{|c|}{ Agree } & Neutral & \multicolumn{1}{c|}{ Disagree } & \multicolumn{1}{|c|}{ N } \\
\hline My stance/attitude towards public secondary schools is positive & $33.3 \%(3)$ & $22.2 \%(2)$ & $44.4 \%(4)$ & 9 \\
\hline The management of public secondary schools is welcoming & $22.2 \%(2)$ & $22.2 \%(2)$ & $55.6 \%(5)$ & 9 \\
\hline $\begin{array}{l}\text { I prefer to relate with public secondary schools to relating with } \\
\text { private secondary schools }\end{array}$ & $22.2 \%(2)$ & $22.2 \%(2)$ & $55.6 \%(5)$ & 9 \\
\hline The image of public secondary schools is very good & $11.1 \%(1)$ & $11.1 \%(1)$ & $77.8 \%(7)$ & 9 \\
\hline MRS & $22.2 \%(8)$ & $26.9 \%(7)$ & $58.3 \%(21)$ & 36 \\
\hline
\end{tabular}

$\chi 2$-test: $\chi 2=11.80 ; \mathrm{df}=2 ; \mathrm{P}=0.003$.

\subsubsection{Journalists' Characterisation of Media Usage in Public Secondary Schools}

On aggregate, $40.3 \%$ of the journalists appreciated the use of media by public secondary schools, with $23.6 \%$ who refused to take sides; but this difference was not statistically significant enough $(\mathrm{P}>0.05)$ to deduce that the media has a good relationship with public secondary schools. $66.7 \%$ (6) and $55.6 \%$ (5) of the journalists agreed that journalists have been invited to be guest speakers in students' activities and career orientation forums and public secondary schools often invite the media to their school programmes for coverage respectively. This is followed by the analysis with equal weights of $44.4 \%$ (4) that some public secondary schools have a media relations policy that outlines a partnership between the school and the media; public secondary schools often send information about their upcoming school activities to media houses and journalists are invited to train students to look for and write news items on happenings around them for publication in their media organs (journalism club). Finally, $33.3 \%$ (3) and $22.2 \%$ (2) of journalists also agreed that public school management uses the media to address pertinent issues related to the school and that public secondary schools have a programme(s)/page(s) reserved for them in media organs, with just $11.1 \%(1)$ of them appreciating the fact that public secondary schools have a good relationship with media organs.

Table3. Journalists' characterisation of media usage in public secondary schools

\begin{tabular}{|l|l|l|l|l|}
\hline \multicolumn{1}{|c|}{ Items } & Agree & Neutral & Disagree & \multicolumn{1}{|c|}{ N } \\
\hline $\begin{array}{l}\text { Some public secondary schools have a media relations policy } \\
\text { that outlines a partnership between the school and the media }\end{array}$ & $44.4 \%(4)$ & $33.3 \%(3)$ & $22.2 \%(2)$ & 9 \\
\hline $\begin{array}{l}\text { Public secondary schools often send information } \\
\text { (announcements) about their upcoming school activities to my } \\
\text { media house }\end{array}$ & $44.4 \%(4)$ & $22.2 \%(2)$ & $33.3 \%(3)$ & 9 \\
\hline $\begin{array}{l}\text { Public secondary schools often invite the media to their school } \\
\text { programmes for coverage }\end{array}$ & $55.6 \%(5)$ & $33.3 \%(3)$ & $11.1 \%(1)$ & 9 \\
\hline $\begin{array}{l}\text { Public secondary schools have a programme(s)/page(s) } \\
\text { reserved for them in media organ }\end{array}$ & $22.2 \%(2)$ & $11.1 \%(1)$ & $66.7 \%(6)$ & 9 \\
\hline $\begin{array}{l}\text { Public secondary schools have a good relationship with the } \\
\text { media }\end{array}$ & $11.1 \%(1)$ & $44.4 \%(4)$ & $44.4 \%(4)$ & 9 \\
\hline $\begin{array}{l}\text { School management uses the media to address pertinent issues } \\
\text { related to the school }\end{array}$ & $33.3 \%(3)$ & $11.1 \%(1)$ & $55.6 \%(5)$ & 9 \\
\hline $\begin{array}{l}\text { Journalists have been invited to be guest speakers in students' } \\
\text { activities and career orientation forums }\end{array}$ & $66.7 \%(6)$ & $11.1 \%(1)$ & $22.2 \%(2)$ & 9 \\
\hline $\begin{array}{l}\text { Journalists are invited to train students to look for and write } \\
\text { news items around them for publication in their media organs } \\
\text { journalism club) }\end{array}$ & $44.4 \%(4)$ & $22.2 \%(2)$ & $33.3 \%(3)$ & 9 \\
\hline MRS & $40.3 \%(29)$ & $23.6 \%(17)$ & $36.1 \%(26)$ & 72 \\
\hline
\end{tabular}

$\chi 2$-test: $\chi 2=3.25 ; \mathrm{df}=2 ; \mathrm{P}=0.197$

\subsubsection{Effect of Journalists' Attitude on Media Usage by Public Secondary Schools}

The attitude of journalists had a weak and non-significant impact on media usage by public secondary schools ( $\mathrm{r}=0.198, \mathrm{P}=0.609)$, therefore implying that a positive attitude of journalists toward secondary schools could slightly trigger PSS usage of the media. In other words, journalists' attitude has little effect on media usage by public secondary schools implying that journalists' attitude has an effect on media usage by public secondary schools. 
Table4. Effect of journalists' attitude on media usage by public secondary schools

\begin{tabular}{|l|l|r|}
\hline \multicolumn{2}{|c|}{} & \multicolumn{1}{|c|}{ Usage of media score } \\
\hline Attitude score journalist & Correlation Coefficient (r) & 0.198 \\
\cline { 2 - 3 } & Sig. (2-tailed) & .609 \\
\cline { 2 - 3 } & $\mathrm{N}$ & 9 \\
\hline
\end{tabular}

\subsubsection{Discussion}

a) PSS Communication Indicators

- Journalists' relationship with public secondary schools

- Journalists' attitude on media usage by public secondary schools

Results reveal a weak relationship between public secondary schools and the media ( $\chi 2$-test: $\chi 2=11.80 ; \mathrm{df}=2 ; \mathrm{P}=0.003)$ and shows that the attitudes of media practitioners have a weak impact on media usage by PSS. This study therefore concludes that school administrators in PSS have not realised the importance of communicating their activities and increasing the visibility of their schools through the media as well as creating good relations with media practitioners. Political and economic reasons could account for this indifference in relations. Since public schools are run by government with tax payers' money [7,8], and given the dependence of these public secondary schools on the administration [8], little flexibility is involved in the management and projection of school activities to stakeholders. Hence, PSS do not see the need to create a strong relationship with the media since they hardly compete for students given their low tuition fees and high demand. However, the most salient element of the crisis management plan is to determine how the school will behave towards the media, and how much information will be passed on which often is dependent on the good relations that the school has with local journalists (www.teachernet.gov.uk).

\subsection{Availability of Means of Communication used by Public Secondary Schools: Administrators' Perspective}

\subsubsection{Communication Means Used by Schools to Communicate with Stakeholders}

School administrators from the 12 schools cited meetings ("the stakeholders meet twice a term to discuss the different measures to be adopted to improve on the morals, discipline and performance of the students") as the most used means of communication between the schools and their stakeholders, followed by phone calls and radio correspondence and letters ("through correspondence (letters) to parents") as well as emails ("e-mail to ex-students") which are used mainly to communicate with school alumni. A majority of the schools do not have websites (12) and for those who do, the administrators assert that it is hardly used to communicate with the stakeholders. Most of the school administrators' believe that public secondary schools need a school website for imagery ("Yes, to sell the image of the school"), information ("Yes, keep the public informed of what is happening in the school"), and communication ("Yes, this will facilitate communication within and out of the environment and enhance the solutions of many problems affecting learning-teaching process") and to be known internationally ("of course, if they say the world is a global village, my school should not be left out").

Table5. Thematic analysis of communication means used by schools to communicate with stakeholders

\begin{tabular}{|c|c|c|c|}
\hline Code & Code Description & $\begin{array}{l}\text { Groundi } \\
\text { ng }\end{array}$ & Quotation \\
\hline \multicolumn{4}{|c|}{ How does your school communicate with its stakeholders? } \\
\hline Audio-visual & $\begin{array}{l}\text { Video Communication whereby } \\
\text { school uses images and words } \\
\text { across distance }\end{array}$ & 0 & \\
\hline Audio & $\begin{array}{l}\text { Communication whereby school } \\
\text { uses only verbal communication } \\
\text { across distance }\end{array}$ & 4 & $\begin{array}{l}\text { "through radio" } \\
\text { "phone calls" }\end{array}$ \\
\hline Print & $\begin{array}{l}\text { Communication on paper within } \\
\text { and out of school }\end{array}$ & 3 & "through correspondences (letters) to parents" \\
\hline
\end{tabular}




\begin{tabular}{|c|c|c|c|}
\hline Meeting & $\begin{array}{l}\text { Communication in an assembly } \\
\text { within and out of school }\end{array}$ & 8 & $\begin{array}{l}\text { "regular meetings with stakeholders" } \\
\text { "the stakeholders meet twice a term to discuss } \\
\text { the different measures to be adopted to improve } \\
\text { on the morals, discipline and performance of } \\
\text { the students" } \\
\text { "PTA meetings are called regularly so that the } \\
\text { parents are actively involved where the } \\
\text { government is not fully involved" } \\
\text { "through the performance of the students } \\
\text { (games, sports, extracurricular activities" }\end{array}$ \\
\hline $\begin{array}{l}\text { Internet (website, } \\
\text { e-mail) }\end{array}$ & $\begin{array}{l}\text { International communication of } \\
\text { school philosophy }\end{array}$ & 2 & "e-mail to ex-students" \\
\hline \multicolumn{4}{|c|}{ Does your school have a website? } \\
\hline Yes & My school has a website & 3 & "yes but not widely used" \\
\hline No & My school does not have a website & 12 & \\
\hline \multicolumn{4}{|c|}{ Do you think your school needs a website and why? } \\
\hline Imagery & $\begin{array}{l}\text { To enhance the identity of the } \\
\text { school across boundaries }\end{array}$ & 4 & "Yes, to sell the image of the school" \\
\hline Information & $\begin{array}{l}\text { Provide and access information } \\
\text { about the school activities }\end{array}$ & 5 & $\begin{array}{l}\text { "Yes, keep the public informed of what is } \\
\text { happening in the school" }\end{array}$ \\
\hline Communication & $\begin{array}{l}\text { Exchange of ideas between the } \\
\text { school and the community }\end{array}$ & 5 & $\begin{array}{l}\text { "Yes, this will facilitate communication within } \\
\text { and out of the environment and enhance the } \\
\text { solutions of many problems affecting learning- } \\
\text { teaching process" } \\
\text { "yes, link the ex-students and well-wishers to } \\
\text { the school"" }\end{array}$ \\
\hline International & $\begin{array}{l}\text { School should be known across the } \\
\text { country }\end{array}$ & 5 & $\begin{array}{l}\text { "of course, if they say the world is a global } \\
\text { village, my school should not be left out" }\end{array}$ \\
\hline
\end{tabular}

\subsubsection{Availability of Communication Means in Schools as Perceived by Students and Teachers}

Analysis reveals that both students (95.2\%) and teachers (85.4\%) regard meetings as the most available means of communication by PSS. This is followed by viewbook/handbook for both the students $(66.0 \%)$ and teachers $(52.1 \%)$. However, the least available means of communication of PSS according to students is the newsletter while for teachers is also the newsletter $(12.5 \%)$ and the school bus $(10.4 \%)$.

Table6. Availability of communication means in schools as perceived by students and teachers

\begin{tabular}{|l|l|l|}
\hline Medium of communication & Students N=1094 & Teachers \\
\hline Viewbook/handbook & $66.0 \%(722)$ & $52.1 \%(25)$ \\
\hline Website & $55.5 \%(607)$ & $22.9 \%(11)$ \\
\hline Newsletter & $32.8 \%(359)$ & $12.5 \%(6)$ \\
\hline E-mail & $53.3 \%(583)$ & $31.3 \%(15)$ \\
\hline Telephone & $40.7 \%(445)$ & $45.8 \%(22)$ \\
\hline Meetings & $95.2 \%(1041)$ & $85.4 \%(41)$ \\
\hline School Bus & $38.8 \%(424)$ & $10.4 \%(5)$ \\
\hline Fliers/brochures & $45.2 \%(495)$ & $33.3 \%(16)$ \\
\hline
\end{tabular}

\subsection{Usage of Communication Means}

\subsubsection{Usage of Communication Means among Students, Teachers and Parents}

Meetings are regarded as the most used form of communication between Public Secondary Schools and students $(98.5 \%)$, teachers $(100 \%)$, and parents $(87.3 \%)$. This is followed by annual reports/letters for students $(83.9 \%)$, teachers $(64.6 \%)$ and parents $(65.5 \%)$. Analysis further reveals that the least means of communication between PSS and their students is the television $(80.5 \%)$ while for teachers it is the school bus $(85.4 \%)$ and for parents television (94.5\%) and e-mail (94.4\%).

Though the three most used channels of communication were the same for the three categories of stakeholders, the extent to which they used it differed significantly ( $\chi 2$-test: $\chi 2=14.79 ; \mathrm{df}=4 ; \mathrm{P}=0.005$ ) indicating that the usage of communication means differs among students, teachers and parents. 
Stakeholders' Appraisal of Public Secondary Schools' Communication in the South West Region of Cameroon

Table7. Usage of communication means as perceived by students, teachers and parents

\begin{tabular}{|c|c|c|c|c|c|c|c|c|c|}
\hline \multirow{2}{*}{$\begin{array}{l}\text { Medium/ } \\
\text { Frequency }\end{array}$} & \multicolumn{3}{|c|}{ Students } & \multicolumn{3}{|c|}{ Teachers } & \multicolumn{3}{|c|}{ Parents } \\
\hline & Often & Sometimes & Never & Often & Sometimes & Never & Often & Sometimes & Never \\
\hline Newspaper & $\begin{array}{l}9.0 \% \\
(98)\end{array}$ & $\begin{array}{l}20.6 \% \\
(225)\end{array}$ & $\begin{array}{l}70.5 \% \\
(771)\end{array}$ & $\begin{array}{l}4.2 \% \\
(2)\end{array}$ & $\begin{array}{l}14.6 \% \\
(7)\end{array}$ & $\begin{array}{l}81.3 \% \\
(39)\end{array}$ & $\begin{array}{l}5.5 \% \\
(3)\end{array}$ & $\begin{array}{l}16.4 \% \\
(9)\end{array}$ & $\begin{array}{l}78.2 \% \\
(43)\end{array}$ \\
\hline Radio & $\begin{array}{l}9.3 \% \\
(102)\end{array}$ & $\begin{array}{l}17.3 \% \\
(189)\end{array}$ & $\begin{array}{l}73.4 \% \\
(803)\end{array}$ & $\begin{array}{l}2.1 \% \\
(1)\end{array}$ & $\begin{array}{l}37.5 \% \\
(18)\end{array}$ & $\begin{array}{l}60.4 \% \\
(29)\end{array}$ & $\begin{array}{l}3.6 \% \\
(2)\end{array}$ & $\begin{array}{l}21.8 \% \\
(12)\end{array}$ & $\begin{array}{l}74.5 \% \\
(41)\end{array}$ \\
\hline Television & $\begin{array}{l}8.0 \% \\
(87)\end{array}$ & $\begin{array}{l}11.5 \% \\
(126)\end{array}$ & $\begin{array}{l}80.5 \% \\
(881)\end{array}$ & $\begin{array}{l}8.3 \% \\
(4)\end{array}$ & $\begin{array}{l}12.5 \% \\
(6)\end{array}$ & $\begin{array}{l}79.2 \% \\
(38) \\
\end{array}$ & $\begin{array}{l}1.8 \% \\
(1)\end{array}$ & $3.6 \%(2)$ & $\begin{array}{l}94.5 \% \\
(52)\end{array}$ \\
\hline E-mail & $\begin{array}{l}11.4 \% \\
(125)\end{array}$ & $\begin{array}{l}16.4 \% \\
(179)\end{array}$ & $\begin{array}{l}72.2 \% \\
(790)\end{array}$ & $\begin{array}{l}10.4 \% \\
(5)\end{array}$ & $\begin{array}{l}16.7 \% \\
(8)\end{array}$ & $\begin{array}{l}72.9 \% \\
(35)\end{array}$ & $\begin{array}{l}1.9 \% \\
(1)\end{array}$ & $3.7 \%(2)$ & $\begin{array}{l}94.4 \% \\
(51)\end{array}$ \\
\hline School website & $\begin{array}{l}18.3 \% \\
(200)\end{array}$ & $\begin{array}{l}19.5 \% \\
(213)\end{array}$ & $\begin{array}{l}62.2 \% \\
(681)\end{array}$ & $\begin{array}{l}4.2 \% \\
(2)\end{array}$ & $\begin{array}{l}18.8 \% \\
(9)\end{array}$ & $\begin{array}{l}77.1 \% \\
(37)\end{array}$ & $\begin{array}{l}9.1 \% \\
(5)\end{array}$ & $7.3 \%(4)$ & $\begin{array}{l}83.6 \% \\
(46)\end{array}$ \\
\hline $\begin{array}{l}\text { Meetings (staff, school } \\
\text { assembly, PTA) }\end{array}$ & $\begin{array}{l}73.8 \% \\
(807)\end{array}$ & $\begin{array}{l}23.7 \% \\
(259)\end{array}$ & $\begin{array}{l}2.5 \% \\
(28)\end{array}$ & \begin{tabular}{|l|}
$68.8 \%$ \\
$(33)$
\end{tabular} & $\begin{array}{l}31.2 \% \\
(15)\end{array}$ & $\begin{array}{l}0.0 \% \\
(0)\end{array}$ & $\begin{array}{l}61.8 \% \\
(34)\end{array}$ & $\begin{array}{l}25.5 \% \\
(14)\end{array}$ & $\begin{array}{l}12.7 \% \\
(7)\end{array}$ \\
\hline \begin{tabular}{|l|} 
Fliers/ \\
Brochures
\end{tabular} & $\begin{array}{l}26.6 \% \\
(291)\end{array}$ & $\begin{array}{l}20.4 \% \\
(223)\end{array}$ & $\begin{array}{l}53.0 \% \\
(580)\end{array}$ & $\begin{array}{l}10.4 \% \\
(5)\end{array}$ & $\begin{array}{l}43.8 \% \\
(21)\end{array}$ & $\begin{array}{l}45.8 \% \\
(22)\end{array}$ & $\begin{array}{l}12.7 \% \\
(7)\end{array}$ & $\begin{array}{l}32.7 \% \\
(18)\end{array}$ & $\begin{array}{l}54.5 \% \\
(30)\end{array}$ \\
\hline Newsletter & $\begin{array}{l}19.6 \% \\
(214)\end{array}$ & $\begin{array}{l}19.7 \% \\
(216)\end{array}$ & $\begin{array}{l}60.7 \% \\
(664)\end{array}$ & $\begin{array}{l}8.3 \% \\
(4)\end{array}$ & $\begin{array}{l}14.6 \% \\
(7)\end{array}$ & $\begin{array}{l}77.1 \% \\
(37)\end{array}$ & $\begin{array}{l}12.7 \% \\
(7)\end{array}$ & $14.5 \%(8)$ & $\begin{array}{l}72.7 \% \\
(40)\end{array}$ \\
\hline Annual reports/letters & $\begin{array}{l}59.3 \% \\
(649)\end{array}$ & $\begin{array}{l}24.6 \% \\
(269)\end{array}$ & $\begin{array}{l}16.1 \% \\
(176)\end{array}$ & $\begin{array}{l}37.5 \% \\
(18)\end{array}$ & $\begin{array}{l}27.1 \% \\
(13)\end{array}$ & $\begin{array}{l}35.4 \% \\
(17)\end{array}$ & $\begin{array}{l}34.5 \% \\
(19)\end{array}$ & $\begin{array}{l}30.9 \% \\
(17)\end{array}$ & $\begin{array}{l}34.5 \% \\
(19)\end{array}$ \\
\hline Memos & $\begin{array}{l}44.6 \% \\
(488)\end{array}$ & $\begin{array}{l}15.5 \% \\
(170)\end{array}$ & $\begin{array}{l}39.9 \% \\
(436)\end{array}$ & $\begin{array}{l}12.5 \% \\
(6)\end{array}$ & $\begin{array}{l}25.0 \% \\
(12)\end{array}$ & $\begin{array}{l}62.5 \% \\
(30)\end{array}$ & $\begin{array}{l}14.5 \% \\
(8)\end{array}$ & $\begin{array}{l}23.6 \% \\
(13)\end{array}$ & $\begin{array}{l}61.8 \% \\
(34)\end{array}$ \\
\hline School Bus & $\begin{array}{l}16.5 \% \\
(181)\end{array}$ & $\begin{array}{l}15.0 \% \\
(164)\end{array}$ & $\begin{array}{l}68.5 \% \\
(749)\end{array}$ & $\begin{array}{l}4.2 \% \\
(2)\end{array}$ & $\begin{array}{l}10.4 \% \\
(5)\end{array}$ & $\begin{array}{l}85.4 \% \\
(41)\end{array}$ & $\begin{array}{l}5.5 \% \\
\text { (3) }\end{array}$ & $5.5 \%(3)$ & $\begin{array}{l}89.1 \% \\
(49)\end{array}$ \\
\hline MRS & $\begin{array}{l}26.9 \% \\
(3242)\end{array}$ & $\begin{array}{l}18.6 \% \\
(2233)\end{array}$ & $\begin{array}{l}54.5 \%( \\
6559)\end{array}$ & \begin{tabular}{|l|}
$15.5 \%$ \\
$(82)$
\end{tabular} & $\begin{array}{l}22.9 \% \\
(121)\end{array}$ & $\begin{array}{l}61.6 \% \\
(325)\end{array}$ & $\begin{array}{l}14.9 \% \\
(90)\end{array}$ & $\begin{array}{l}16.9 \% \\
(102)\end{array}$ & \begin{tabular}{|l}
$68.2 \%(4$ \\
$12)$
\end{tabular} \\
\hline
\end{tabular}

$\chi 2$-test: $\chi 2=14.79 ; \mathrm{df}=4 ; \mathrm{P}=0.005$.

\subsubsection{Satisfaction with the Communication Means in Schools}

The most comfortable means of communication for students with the school is meetings with $68.6 \%$ followed by annual reports/letters $(59.4 \%)$ with the least preferred medium of communication being the newspaper and radio with equal ratings of $34.6 \%$. Teachers considered newsletters, fliers and brochures as their most preferred means of communication with the school, with equal ratings of 93.7\% although newsletters (62.5\%) were considered as the more comfortable means of communication to fliers and brochures $(58.3 \%)$. This is followed by e-mails and memos with equal ratings of $89.6 \%$ with the least comfortable means of communication being meetings $(58.3 \%)$. The email was considered the most comfortable means of communication by teachers, with a percentage of $81.3 \%$. Parents on the other hand were more comfortable with every means of communication with PSS and cited meetings (43.6\%) as the most comfortable means of communication with the school followed by annual reports and letters (21.8\%), with the least being e-mails (1.8\%).

Table8. Satisfaction with the communication means in schools as perceived by students, teachers and parents

\begin{tabular}{|c|c|c|c|c|c|c|c|c|c|}
\hline \multirow{2}{*}{$\begin{array}{c}\text { Medium/ } \\
\text { convenience }\end{array}$} & \multicolumn{3}{|c|}{ Students } & \multicolumn{3}{|c|}{ Teachers } & \multicolumn{3}{|c|}{ Parents } \\
\hline & $\begin{array}{c}\text { Comfort } \\
\text { able }\end{array}$ & $\begin{array}{c}\text { Partially } \\
\text { comfort } \\
\text { able }\end{array}$ & $\begin{array}{c}\text { Not } \\
\text { comforta } \\
\text { ble }\end{array}$ & $\begin{array}{l}\text { Comfo } \\
\text { rtable }\end{array}$ & $\begin{array}{c}\begin{array}{c}\text { Partially } \\
\text { comfort } \\
\text { able }\end{array} \\
\text { ald }\end{array}$ & $\begin{array}{c}\text { Not } \\
\text { comforta } \\
\text { ble }\end{array}$ & $\begin{array}{c}\text { Comfor } \\
\text { table }\end{array}$ & $\begin{array}{c}\text { Partially } \\
\text { comforta } \\
\text { ble }\end{array}$ & $\begin{array}{c}\text { Not } \\
\text { comforta } \\
\text { ble }\end{array}$ \\
\hline Newspaper & $\begin{array}{l}34.6 \% \\
(379)\end{array}$ & $\begin{array}{l}0.0 \% \\
(0)\end{array}$ & $\begin{array}{l}65.4 \% \\
(715)\end{array}$ & \begin{tabular}{|l|}
$56.3 \%$ \\
$(27)$
\end{tabular} & $\begin{array}{l}25.0 \% \\
(12)\end{array}$ & $\begin{array}{l}18.8 \% \\
(9)\end{array}$ & \begin{tabular}{|l}
$7.3 \%$ \\
$(4)$ \\
\end{tabular} & $\begin{array}{l}92.7 \% \\
51)\end{array}$ & $\begin{array}{l}0.0 \% \\
(0)\end{array}$ \\
\hline Radio & $\begin{array}{l}33.1 \% \\
(362)\end{array}$ & $\begin{array}{l}1.6 \% \\
(17)\end{array}$ & \begin{tabular}{|l|}
$65.4 \%$ \\
$(715)$
\end{tabular} & \begin{tabular}{|l|}
$56.3 \%$ \\
$(27)$ \\
\end{tabular} & $\begin{array}{l}29.2 \% \\
(14)\end{array}$ & $\begin{array}{l}14.6 \% \\
(7)\end{array}$ & \begin{tabular}{|l|}
$5.5 \%$ \\
$(3)$ \\
\end{tabular} & $\begin{array}{l}94.5 \% \\
(52)\end{array}$ & $\begin{array}{l}0.0 \% \\
(0)\end{array}$ \\
\hline Telev & $\begin{array}{l}41.4 \% \\
(453)\end{array}$ & $\begin{array}{l}1.7 \% \\
(19)\end{array}$ & $\begin{array}{l}56.9 \% \\
(622)\end{array}$ & $\begin{array}{l}50.0 \% \\
(24)\end{array}$ & $\begin{array}{l}29.2 \% \\
(14)\end{array}$ & $\begin{array}{l}20.8 \% \\
(10)\end{array}$ & $\begin{array}{l}3.6 \% \\
(2)\end{array}$ & $\begin{array}{l}96.4 \% \\
(53)\end{array}$ & $\begin{array}{l}0.0 \% \\
(0)\end{array}$ \\
\hline E-mail & $\begin{array}{l}33.5 \% \\
(367)\end{array}$ & $\begin{array}{l}1.7 \% \\
(19)\end{array}$ & $\begin{array}{l}64.7 \% \\
(708)\end{array}$ & $\begin{array}{l}81.3 \% \\
(39)\end{array}$ & $\begin{array}{l}8.3 \% \\
(4)\end{array}$ & $\begin{array}{l}10.4 \% \\
(5)\end{array}$ & $\begin{array}{l}1.8 \% \\
(1)\end{array}$ & $\begin{array}{l}98.2 \% \\
(54)\end{array}$ & $\begin{array}{l}0.0 \% \\
(0)\end{array}$ \\
\hline School & $\begin{array}{l}37.1 \% \\
(406)\end{array}$ & $\begin{array}{l}2.4 \% \\
(26)\end{array}$ & $\begin{array}{l}60.5 \% \\
(662)\end{array}$ & $\begin{array}{l}54.2 \% \\
(26)\end{array}$ & $\begin{array}{l}29.2 \% \\
(14)\end{array}$ & $\begin{array}{l}16.7 \% \\
(8)\end{array}$ & $\begin{array}{l}7.3 \% \\
(4)\end{array}$ & $\begin{array}{l}92.7 \% \\
(51)\end{array}$ & $\begin{array}{l}0.0 \% \\
(0)\end{array}$ \\
\hline Meetings & $7.8 \%$ & $0.8 \%$ & $31.4 \%$ & $35.4 \%$ & $22.9 \%$ & $41.7 \%$ & $43.6 \%$ & $56.4 \%$ & $0.0 \%$ \\
\hline
\end{tabular}


Stakeholders' Appraisal of Public Secondary Schools' Communication in the South West Region of Cameroon

\begin{tabular}{|c|c|c|c|c|c|c|c|c|c|}
\hline $\begin{array}{l}\text { school assembly, } \\
\text { PTA) }\end{array}$ & $(742)$ & (9) & (343) & (17) & $(11)$ & $(20)$ & (24) & (31) & $(0)$ \\
\hline Fliers/brochures & $\begin{array}{l}35.6 \% \\
(389)\end{array}$ & $\begin{array}{l}2.3 \% \\
(25)\end{array}$ & $\begin{array}{l}62.2 \% \\
(680)\end{array}$ & $\begin{array}{l}58.3 \% \\
(28)\end{array}$ & $\begin{array}{l}35.4 \% \\
(17)\end{array}$ & $\begin{array}{l}6.3 \% \\
(3)\end{array}$ & $\begin{array}{l}10.9 \% \\
(6)\end{array}$ & $\begin{array}{l}89.1 \% \\
(49)\end{array}$ & $\begin{array}{l}0.0 \% \\
(0)\end{array}$ \\
\hline Newsletter & $\begin{array}{l}37.0 \% \\
(405)\end{array}$ & $\begin{array}{l}2.6 \% \\
(28)\end{array}$ & $\begin{array}{l}60.4 \% \\
(661)\end{array}$ & $\begin{array}{l}62.5 \% \\
(30)\end{array}$ & $\begin{array}{l}31.3 \% \\
(15)\end{array}$ & $\begin{array}{l}6.3 \% \\
(3)\end{array}$ & $\begin{array}{l}7.3 \% \\
(4)\end{array}$ & $\begin{array}{l}92.7 \% \\
(51)\end{array}$ & $\begin{array}{l}0.0 \% \\
(0)\end{array}$ \\
\hline $\begin{array}{l}\text { Annual } \\
\text { reports/letters }\end{array}$ & $\begin{array}{l}58.2 \% \\
(637)\end{array}$ & $\begin{array}{l}1.2 \% \\
(13)\end{array}$ & $\begin{array}{l}40.6 \% \\
(444)\end{array}$ & $\begin{array}{l}41.7 \% \\
(20)\end{array}$ & $\begin{array}{l}33.3 \% \\
(16)\end{array}$ & $\begin{array}{l}22.9 \% \\
(11)\end{array}$ & $\begin{array}{l}21.8 \% \\
(12)\end{array}$ & $\begin{array}{l}78.2 \% \\
(43)\end{array}$ & $\begin{array}{l}0.0 \% \\
(0)\end{array}$ \\
\hline Memos & $\begin{array}{l}48.3 \% \\
(528)\end{array}$ & $\begin{array}{l}2.8 \% \\
(31)\end{array}$ & $\begin{array}{l}48.9 \% \\
(535)\end{array}$ & $\begin{array}{l}62.5 \% \\
(30)\end{array}$ & $\begin{array}{l}25.0 \% \\
(12)\end{array}$ & $\begin{array}{l}10.4 \% \\
(5)\end{array}$ & $\begin{array}{l}18.2 \% \\
(10)\end{array}$ & $\begin{array}{l}81.8 \% \\
(45)\end{array}$ & $\begin{array}{l}0.0 \% \\
(0)\end{array}$ \\
\hline
\end{tabular}

\subsubsection{Discussion}

a) Usage of communication means as perceived by students, teachers and parents.

School administrators from the 12 schools cited meetings as the most used means of communication between the schools and their stakeholders, followed by phone calls and radio broadcasts and letters; the latter being used mainly to communicate with school alumni. According to the school administrators, a majority of the schools do not have websites and for those that do, the administrators assert that it is hardly used to communicate with the stakeholders.

On the other hand, quantitative results reveal that PSS use varied means to communicate with their stakeholders, including meetings, handbook, e-mail, and telephone. However, the preferred contacts for teachers included fliers and brochures (93.7\%), newsletters and letters (93.7\%), emails (89.6), memos $(89.6 \%)$; with emails listed as the most comfortable means. This finding can lead to the conclusion that though meetings which required immediate feedback were heavily cited as means via which schools communicate with teachers, students and parents, the preferred method of contact for teachers was the print publications which do not require immediate feedback. These preferred methods of contact for teachers could be explained by the school administrator's bureaucracy in the institutionalisation of power $[3,4]$ which at times impedes openness in the communication of ideas as well as dissatisfaction among teachers [5]. Hence, the majority of teachers preferred the printed version of communication (newsletters, memos, fliers, brochures, emails) which do not call for immediate feedback and direct face-to face contact as opposed to meetings revealed by school administrators as most used communication means.

Though the three most used channels of communication by teachers, students and parents (meetings, annual reports/letters and memos) were the same, the extent to which they used them differed significantly ( $\chi 2$-test: $\chi 2=14.79 ; \mathrm{df}=4 ; \mathrm{P}=0.005)$. This could be due to the fact that each stakeholder has a different interest and influence in the school and so the degree to which the school institution communicates with them differs, as well as the communication strategy used [22, 23].

\subsection{Communication between Schools and Stakeholders: School Accountability to Stakeholders}

\subsubsection{Public secondary schools (PSS) in the SW Region accountability to their stakeholders (students and teachers)}

Overall, $55.7 \%$ of the students and $44.5 \%$ of teachers actually agreed with the indicators that measured the accountability of schools to stakeholders with $13.4 \%$ of the students neither agreeing nor disagreeing. 86.3\% (944) and 78.0\% (853) of the students and 81.3\%(39) and 54.2\%(26) of the teachers were of the opinion that their schools have open disciplinary discussions and sanction meetings with parents/students and the school management explains the mission, vision and values of the schools and they know what their schools represent in terms of logo, disciplinary measures, motto, rules and regulations and structure respectively. 61.9\% (677), 61.7\% (675) and 61.5\% (673) of the students and $81.3 \%(39), 52.1 \%(25), 43.8 \%(21)$ of the teachers were also in support of the views that their schools have and make available a calendar of school activities, provide information about accomplishments and/or failures of the school, and ascertain that their schools have open house discussions with the council/community/partners/alumni of the school respectively. This was followed by $56.2 \%(615)$ of the students who also abide by the statements that their schools have a database for parents/guardians/teachers addresses (telephone, e-mail) which it uses to invite them for PTA meetings and other issues. This result was below the average for teachers $39.6 \%$ ( 19).

Results further revealed that the students perceived that their school management averagely explains actions and decisions that may appear inconsistent, unfair and secretive 55.5\% (607) and encourages 
students/teachers to come with concerns, suggestions and ideas 54.7\%(598). $15.9 \%(174)$ chose to be neutral. The prior statement was below average for teachers $37.5 \%$ (18) with the later depicting an average score of $56.3 \%$ (27). $53.7 \%$ (588) of students interviewed believed that their school had a department in charge of communication while only $27.1 \%$ (13) of teachers agreed with that remark. Just $28.4 \%$ (311) and $14.5 \%$ (159) of the students confirmed the availability of a dynamic website to inform community about the activities of the school and the school running radio/television programmes that deal with issues regarding their school. Teachers disproved these statements with equal percentages of $8.3 \%(4)$.

In conclusion, teachers and students had almost the same level of satisfaction $(\mathrm{P}>0.05)$ and the difference between the satisfied and the non-satisfied was not significant $(\mathrm{P}>0.05)$, therefore revealing that public secondary schools (PSS) in the SW Region are not accountable to their stakeholders.

Table9. Accountability of schools to stakeholders as perceived by students and teachers

\begin{tabular}{|l|l|l|}
\hline & \multicolumn{1}{|c|}{ Students } & \multicolumn{1}{|c|}{ Teachers } \\
\hline My school has a department in charge of communication. & $53.7 \%(588)$ & $27.1 \%(13)$ \\
\hline $\begin{array}{l}\text { My school has a radio/television programme that deals with issues } \\
\text { regarding the school }\end{array}$ & $14.5 \%(159)$ & $8.3 \%(4)$ \\
\hline My school has and makes available a calendar of school activities & $61.9 \%(677)$ & $81.3 \%(39)$ \\
\hline $\begin{array}{l}\text { My school has open house discussions with the } \\
\text { council/community/partners/alumni of the school }\end{array}$ & $61.5 \%(673)$ & $43.8 \%(21)$ \\
\hline $\begin{array}{l}\text { My school has open disciplinary discussions and sanction meetings with } \\
\text { parents and students }\end{array}$ & $86.3 \%(944)$ & $81.3 \%(39)$ \\
\hline $\begin{array}{l}\text { My school has a dynamic website to inform community about the } \\
\text { activities of the school }\end{array}$ & $28.4 \%(311)$ & $8.3 \%(4)$ \\
\hline $\begin{array}{l}\text { My school has a database (record) of parents/guardians/ teachers } \\
\text { addresses (telephone, e-mail) which it uses to invite them for PTA } \\
\text { meetings and other issues }\end{array}$ & $56.2 \%(615)$ & $39.6 \%(19)$ \\
\hline $\begin{array}{l}\text { The school management encourages us to come to them with concerns, } \\
\text { suggestions and ideas }\end{array}$ & $54.7 \%(598)$ & $56.3 \%(27)$ \\
\hline $\begin{array}{l}\text { Information about accomplishments and/or failures of the school are } \\
\text { readily available }\end{array}$ & $61.7 \%(675)$ & $52.1 \%(25)$ \\
\hline $\begin{array}{l}\text { The school management explains actions and decisions that may appear } \\
\text { inconsistent, unfair and secretive }\end{array}$ & $55.5 \%(607)$ & $37.5 \%(18)$ \\
\hline $\begin{array}{l}\text { The school management explains the mission, vision and values of this } \\
\text { school and I know what my school represents in terms of logo, } \\
\text { disciplinary measures motto, rules and regulations, structure }\end{array}$ & $78.0 \%(853)$ & $54.2 \%(26)$ \\
\hline MRS & $55.7 \%(6700)$ & $44.5 \%(235)$ \\
\hline
\end{tabular}

$\chi 2$-test: $\chi 2=2.64 ; \mathrm{df}=1 ; \mathrm{P}=0.104$.

\subsubsection{Accountability of Schools to Stakeholders as Perceived by Students by Background Indicators}

In urban areas, PSS were significantly $(\mathrm{P}<0.05)$ more accountable to stakeholders, with a proportion of $57.9 \%$ as compared to $47.6 \%$ for the rural ones. The difference between first and second cycles was not significant.

Table10. Accountability of schools to stakeholders as perceived by students by background indicators

\begin{tabular}{|c|c|c|c|c|c|c|}
\hline \multirow[t]{2}{*}{ Indicator } & \multirow[t]{2}{*}{ Categories } & \multicolumn{3}{|c|}{ Satisfied with the accountability of school } & \multirow[t]{2}{*}{$\mathbf{N}_{\text {responses }}$} & \multirow{2}{*}{$\begin{array}{l}\text { Chi- } \\
\text { Square }\end{array}$} \\
\hline & & Agree & Neutral & Disagree & & \\
\hline \multirow{2}{*}{$\begin{array}{l}\text { Setting } \\
\text { type }\end{array}$} & Rural & $47.6 \%(1219)$ & $12.0 \%(307)$ & $40.5 \%(1037)$ & 2563 & \multirow{2}{*}{$\begin{array}{l}\chi^{2}=7.91 \\
P=0.005\end{array}$} \\
\hline & Urban & $57.9 \%(5481)$ & $13.8 \%(1308)$ & $28.3 \%(2682)$ & 9471 & \\
\hline \multirow[t]{2}{*}{ Cycle } & First cycle & $54.8 \%(3878)$ & $12.0 \%(852)$ & $33.1 \%(2343)$ & 7073 & \multirow{2}{*}{$\begin{array}{l}\chi 2=0.54 \\
P=0.463\end{array}$} \\
\hline & $\begin{array}{l}\text { Second cycle (lower } \\
\text { sixth and upper sixth) }\end{array}$ & $56.9 \%(2822)$ & $15.4 \%(763)$ & $27.7 \%(1376)$ & 4961 & \\
\hline
\end{tabular}

\subsubsection{Parents Characterisation of Communication between Schools and Parents}

On aggregate, $56.8 \%$ making significantly the higher proportion $(\mathrm{P}<0.05)$ agreed with the indicators that measured communication between schools and parents with $9.3 \%$ neither agreeing nor disagreeing. However, majority of the parents, that is $83.6 \%$ (46), agreed that school formally invites 
parents/guardians to PTA meetings with well-articulated agendas, followed by school notification of parents about their children's progress and that schools formally invite parents to disciplinary meetings of their children with equal weights of $69.1 \%(38) .58 .2 \%(32), 54.5 \%(30)$ and $50.9 \%(28)$ further agreed that schools provide information about the calendar of activities for the academic year, give parents timely notice when the performance of their children is dropping, and when the child is stubborn or wayward, and the school managements encourage them and are open to concerns, suggestions and ideas. Finally, 49.1\% (27), 40.0\% (22) and 36.4\% (20) also agree that schools provide information about their accomplishments, grading policies and explain actions and decisions that may appear inconsistent, unfair and secretive.

Conclusively, parents demonstrated some level of satisfaction with the school accountability (P < 0.05), therefore implying that public secondary schools (PSS) in the SW Region are accountable to their stakeholders, specifically parents.

Table11. Parents Characterisation of communication between schools and parents

\begin{tabular}{|l|c|l|l|c|}
\hline \multicolumn{1}{|c|}{ Statements } & Agree & Neutral & Disagree & N \\
\hline $\begin{array}{l}\text { This school notifies parents about their child's progress or } \\
\text { insight on their improvement }\end{array}$ & $69.1 \%(38)$ & $5.5 \%(3)$ & $25.5 \%(14)$ & 55 \\
\hline $\begin{array}{l}\text { This school gives to parents timely notice when the } \\
\text { performance of their children is slipping/dropping and } \\
\text { when the child is stubborn or wayward }\end{array}$ & $54.5 \%(30)$ & $3.6 \%(2)$ & $41.8 \%(23)$ & 55 \\
\hline $\begin{array}{l}\text { This school provides information about the calendar of } \\
\text { activities for the academic year }\end{array}$ & $58.2 \%(32)$ & $3.6 \%(2)$ & $38.2 \%(21)$ & 55 \\
\hline $\begin{array}{l}\text { This school provides information on homework and } \\
\text { grading policies }\end{array}$ & $40.0 \%(22)$ & $5.5 \%(3)$ & $54.5 \%(30)$ & 55 \\
\hline $\begin{array}{l}\text { This school formally invites parents/guardians to PTA } \\
\text { meetings with agenda well-articulated }\end{array}$ & $83.6 \%(46)$ & $3.6 \%(2)$ & $12.7 \%(7)$ & 55 \\
\hline $\begin{array}{l}\text { This school formally invites parents to disciplinary } \\
\text { meetings of their children }\end{array}$ & $69.1 \%(38)$ & $12.7 \%(7)$ & $18.2 \%(10)$ & 55 \\
\hline $\begin{array}{l}\text { The school management encourages us to come to them (is } \\
\text { open) with concerns, suggestions and ideas }\end{array}$ & $50.9 \%(28)$ & $16.4 \%(9)$ & $32.7 \%(18)$ & 55 \\
\hline $\begin{array}{l}\text { Information about accomplishments and/or failures of the } \\
\text { school are readily available }\end{array}$ & $49.1 \%(27)$ & $16.4 \%(9)$ & $34.5 \%(19)$ & 55 \\
\hline $\begin{array}{l}\text { The school management explains actions and decisions that } \\
\text { may appear inconsistent, unfair and secretive }\end{array}$ & $36.4 \%(20)$ & $16.4 \%(9)$ & $47.3 \%(26)$ & 55 \\
\hline MRS & $56.8 \%(281)$ & $9.3 \%(46)$ & $33.9 \%(168)$ & 495 \\
\hline
\end{tabular}

$\chi 2$-test: $\chi 2=5.28 ; \mathrm{df}=1 ; \mathrm{P}=0.021$.

\subsubsection{Parents' Views on Communication between Schools and Parents by Background Indicators}

As far as parents' characterisation of communication between school and parents was concerned, the trend was positive in both rural and urban areas although in the rural areas parents were slightly more satisfied, with a proportion of $58.2 \%$ as against $55.1 \%$ in urban areas. However, this difference was not significant $(\mathrm{P}>0.05)$.

In terms of public and private schools, parents were relatively more satisfied with private schools (66.7\%) than with public schools (55. 1\%); but this difference was not significant $(\mathrm{P}>0.05)$.

Table12. Parents'views on communication between schools and parents by background indicators

\begin{tabular}{|l|l|l|l|l|l|l|}
\hline Indicators & Categories & \multicolumn{3}{|l|}{$\begin{array}{l}\text { Satisfied with communication between schools and } \\
\text { parents }\end{array}$} & $\mathbf{N}_{\text {responses }}$ & $\begin{array}{l}\text { Chi- } \\
\text { Square }\end{array}$ \\
\cline { 3 - 6 } & & Agree & Neutral & Disagree & & \\
\hline Setting type & Rural & $58.2 \%(152)$ & $10.0 \%(26)$ & $31.8 \%(83)$ & 261 & $\chi 2=0.13$ \\
\cline { 2 - 7 } & Urban & $55.1 \%(129)$ & $8.5 \%(20)$ & $36.3 \%(85)$ & 234 & $\mathrm{p}=0.721$ \\
\hline \multirow{2}{*}{$\begin{array}{l}\text { Where are the } \\
\text { children } \\
\text { schooling }\end{array}$} & Public & $55.1 \%(233)$ & $8.0 \%(34)$ & $36.9 \%(156)$ & 423 & $\chi 2=0.16$ \\
\cline { 2 - 6 } & Private & $66.7 \%(48)$ & $16.7 \%(12)$ & $16.7 \%(12)$ & 72 & $\mathrm{p}=0.693$ \\
\hline
\end{tabular}




\subsubsection{Discussion}

a) Public secondary schools (PSS) in the SW Region accountability to their stakeholders (teachers, students and parents)

There is evidence that public secondary schools are somewhat accountable to teachers and students with the same average level of satisfaction $(\mathrm{P}>0.05)$; but the difference between the satisfied teachers and students and the unsatisfied was not significant $(\mathrm{P}>0.05)$, thereby leading to the conclusion that public secondary schools (PSS) in the SW Region are not accountable to teachers and students. The poor accountability is a reflection of the bureaucratic structure of most public secondary schools in Cameroon [3] whereby there is centralisation in the decision-making process, with decision-making concentrated at the top [24]. Also, results revealed that most of PSS do not have a communications department (teachers $-27.1 \%$ (13); students - 53.7\% (588)) which could serve as a source of information circulation for the school stakeholders as purported by [3]. Hence, most often, relevant information about the school does not reach stakeholders who are thus left to depend on grapevine for communication, with its attendant effect on their perception of the image of PSS. [24], and many others have stated that public relations make organisations more effective by building relationships with stakeholders. They need to both disseminate to and seek information from their publics in order to operate successfully. When organisations forget or ignore the importance of public relations in their organisational structure, this may often result in dissatisfaction among their stakeholders. [22], [21] assert that organisations should be accountable to their legitimate stakeholders financially, socially (social responsibility, community involvement, labour involvement) as well as ecologically (reduction of harmful waste) as such accountability helps the organisation to be viewed favourably by the different stakeholders.

However, Parents demonstrated some level of satisfaction with the school accountability $(\mathrm{P}<0.05)$, therefore leading to the conclusion that public secondary schools (PSS) in the SW Region are accountable to parents. This accountability is evident in PTA meetings scheduled by School administration to communicate with parents about school activities 83.6\% (46), updates about children's progress $69.1 \%(38)$ as well as invitation to disciplinary meetings of their children 69.1\%(38). Interpersonal communication dominates as a means of communicating with parents and this is supported by [14], [27] who emphasise that interpersonal communication is widely used by schools as it is the major determinant of stakeholder's attitude and behaviour. Also, parents are more satisfied with school accountability because schools consider them as key stakeholders that can influence the education of the child as well as the wellbeing of the school, hence PTA meetings to communicate with them regularly.

\section{CONCLUSION}

Stakeholders of Public secondary schools in the South West Region are not satisfied with the school's communication due to inadequacy of media relations policy, inadequate usage of the diverse medium of communication available in the schools, lack of strategic communication tools such as school websites necessary to increase the schools' visibility, as well as poor social policy which limits their interaction with their stakeholders. Hence, effective communication is necessary to disseminate school activities through various media. The powers of websites and social media have been recognised in the present society. Hence, studying the impact of each communication channel used by schools to reach their stakeholders could provide a guideline for educators; hence the recommendation for further research.

\section{REFERENCES}

[1] Growth and Employment Strategy Paper - GESP (2009). Reference framework for Government Action over the period of 2010 -2020. Republic of Cameroon.

[2] National Institute of Statistics (2010). Second survey on the monitoring of public expenditures and the level of recipients' satisfaction in the education and health sectors in Cameroon (PETS2) - education section, Cameroon

[3] Mbua, N. F. (2003). Educational Administration Theory and Practice: The Management of Organisations and individuals. Limbe, DESIGN HOUSE.

[4] Edwards, R. (1979). Contested terrain: The transformation of the work place in the twentieth century. London, Heinemann. 
[5] Ekwutosi, O. C. \& Moses, O.S. (2013). Internalisation of organisational culture: A Theoretical perspective. International Journal of Business Tourism and Applied Sciences Vol. 1 No.2 July-December, 2013 http://www.ijbts-journal.com

[6] Draft Document of the Sector Wide Approach/Education (2006). MINEDUB-MINESEC-MINEFOPMINESUP, Cameroon.

[7] Jimenez, E., Lockheed, M. E., Cox, D., Luna, E., Paqueo, V., De Vera, M. L. \& Wattanawaha, N. (1995). Public and Private Secondary Education in Developing Countries: A Comparative Study. Washington, D.C.: The World Bank.

[8] Dronkers, J. \& Robert, P (2003). The effectiveness of public and private schools from a comparative perspective. San Domenso, European University Institute of Badia Fiesolana.

[9] Carlsmith L. \& Railsback, J. (2001). The Power of public relations in schools communications perspective. Brand Management, Vol.12, No.4, pp. 264-278

[10] Abah, I. (2014, March 17). BHS Buea lynching: Victim's brother, girlfriend seeks legal action. The Post Newspaper, 01513, pp. 2.

[11] Nana, W. W. (2014, November 17). Student Stabs another to Death. The Post Newspaper, 01481, pp. 8.

[12] Sumelong, E. (2013, December 27). Principal slammed 11 years for child trafficking. The Post Newspaper, 01491, pp. 3.

[13] Mokake, E. E.., (2014, February 24). 13-year old grabs best speller prize. The Post Newspaper, 01507, pp. 10.

[14] Obi, E. (1997). Communication and the management of organisational behaviour in Ndu, A. N., Ocho, L. O., Okeke, B. S. (1997). Dynamics of Educational Administration and management. Awka, Anambra state, Meks publisher.

[15] Birkigt, K \& Stadler, M (1986). Corporate Identity: Grundlagen, Funktionen und Beispielen. Landsberg an Lech:verlag Moderne Industrie.

[16] Almaney, A. (1974). Communication and the systems theory of organisations. Journal of Business Communication, Vol. 35. http://job.sagepub.com/content/12/1/35. Accessed, 23 May 2014.

[17] Van Riel, C. B. M. (1995). Principles of Corporate Communication. Prentice Hall, Hertfordshire/ England.

[18] McCladdie, Henry H. Jr. (2017). A Case Study Focused on the Level of Satisfaction of Select Stakeholders: Parents, Teachers, and Community Members on Identified Variables to Improve Academic Performance in One Urban Charter School. Electronic Theses \& Dissertations Collection for Atlanta University \& Clark Atlanta University. 84.http://digitalcommons.auctr.edu/cauetds/84

[19] Freeman, R. E. (1984). Strategic management: A stakeholder approach. Pitman, Boston.

[20] Friedman, M. (1970). The social responsibility of business is to increase its profits', The New York Times Magazine, September 13.

[21] Donaldson, T. \& Preston, L. E. (1995). The stakeholder's theory of the corporation: concepts, evidence and implications. Academy of Management Review, Vol. 20, No. 1, pp.65-91.

[22] Cornelissen, J., (2008). Corporate communication: Theory and practice. London: SAGE Publication Ltd

[23] Carroll, A. B. (1989). Business and society: ethics and stakeholder management. Cincinatti OH: South Western Publishing, pp. 62

[24] Grunig, L.A., Grunig, J. E. \& Dozier, D. M. (2002). Excellent public relations and effective organisations: A study of communication management in three countries (pp 483 - 501). Hillsdale, NJ: Lawrence Erlbaum Associates. Google.

[25] Ni, L. (2006). Exploring the value of public relations in strategy implementation: Employee relations in globalization process. Unpublished doctoral dissertation, University of Maryland, College Park. North West Regional Educational Laboratory, Oregon

[26] Rhee, Y. (2004). The employee-public-organization chain in relationship management: A case study of a government organization. Unpublished doctoral dissertation, University of Maryland, College Park.

[27] White, C. Vanc, A., and Stafford, G. (2010). Internal communication, information satisfaction and sense of community: the effect of personal influence. Journal of Public Relations, Vol 22, issue 1.

[28] Edelman, D.C. (2010). Branding in the digital age, You're spending your money in all the wrong places. Harvard Business Review, 88, 63 - 69.

[29] Bartoo, H. And Sias, P.M. (2004). When enough is too much: communication apprehension and employee information experiences. Communication Quarterly, Vol 52, No 1, pp 15-26.

[30] Rosenfeld, L, B., Richman, J.M. and May S.K. (2004). Information adequacy, job satisfaction and organisational culture in a dispersed network organisation. Journal of Applied Communication Research, Vol 32. No 1, pp 28-54. 
[31] Zucker, R. (2002). More than a name change - internal branding at Pearl. Strategic Communication Management, Vol 6, No 4 pp 24 -27.

[32] Men, L. R. (2011). Exploring the impact of employee empowerment on organisation-employee relationship. Public Relations Review, in press

[33] Meyer, A., Gaba, V., and Cowell, K. (2005). Organising far from equilibrium: Nonlinear change in organisational fields. Organisation Sciences, ISSN 10477039, Vol. 16, pp. 456-473.

[34] Witmer, D. (2006). Overcoming systems and culture boundaries: public relations from a structuration perspective. In Botan, C \& Hazelton, V. Public Relations Theory II. (pp361 - 371). Mahwah, NJ: Lawrence Erlbaum.

[35] Cornelissen, J. \& Harris, P. (2001). Corporate identity metaphor: Perspectives, problems and prospects. Journal of Marketing Management, Issue17, pp. 49 - 71.

[36] Mbua, F.N. (2002). Educational Planning: Issues and Perspectives, Limbe Presprint

[37] Foskett, N. (1992). Managing External Relations in Schools. Routledge, London.

[38] Bunnell, T. (2005). Strategic marketing planning in international schools. International Journal of Educational Management, Vol. 19 No. 1, pp. 59-66

[39] Oplatka, I. (2002). The emergence of educational marketing: lessons from the experiences of Israeli principals. Comparative Education Review, Vol. 46, No. 2, pp. 211-33.

[40] Hyde, M. W. (1936). Educational publicity. The Journal of Higher Education, Vol7, No 1. Pp 134- 137.

[41] Oplatka, T and Hemsley-Brown, J. (2004). Journal of Educational Administration, Vol 42, no 3, pp 375 - 400.

[42] Bell, L. (1999). "Primary schools and the nature of the education market place", in Bush, T., Bell, L., Bolam, R., Glatter, R. and Ribbins, P. (Eds), Educational management: Redefining theory, policy, practice, Paul Chapman

[43] Furse, J. (1989). Marketing in primary school. In FIdler, B. And Browles, G. (Eds) Effective local Management of schools. Longman. London.

[44] Goldring, E. B and Rallis, S. (1993). Principals of Dynamic Schools. Corwin and Sage, Newbury Park CA.

[45] Lucey, T. (1987). Management information system. ELBS Pub. $5^{\text {th }}$ Edition

[46] Mbiti, D. (1974). Foundation of School administration. Oxford University Press

[47] Manafo, M. J. (2006). Enhancing the value of public education: Lesson from the private sector. Phi Delta Kappan.manafo@post.havard.edu

[48] Marzano, R.J., Waters, T., \& McNulty, B. A. (2005). School Leadership that Works: From Research to Results. Aurora, Colorado, Mid-continent Research for Education and Learning (McREL).

[49] Josué, T. T. (2007). ICT in education in Cameroon, Survey of ICT and education in Africa: Cameroon country report. Journal of Marketing Management, Vol: 14, pp. 963-96.

[50] Plomp, T.; Pelgrum, W. J. \& Law, N. (2007). SITES2006-International comparative survey of pedagogical practices and ICT in education. Education and Information Technologies Vol.12, No. ), Pp; 83-92.

[51] Lim, C. P. \& Chai, C.S. (2004). An activity-theoretical approach to research of ICT integration in Singapore schools: Orienting activities and learner autonomy', Computers \& Education, Vol. 43, No. 3, pp; 215--236.

[52] Bhattacharya, I. \& Sharma, K. (2007). India in the knowledge economy - an electronic paradigm. International Journal of Educational Management Vol. 21 No. 6, Pp. 543- 568

[53] Johnson, R. B., Onwuegbuzie, A. J., \& Turner, L. A. (2007). Toward a definition of mixed methods research. Journal of mixed methods research, Vol. 1, No.2, pp.112-133. doi: 10.1177/1558689806298224

[54] Creswell, J. W. (2003). Research design: Qualitative, quantitative and mixed methods Approaches. London, Sage Publications, 2nd ed.

[55] Yin, R. K. (2008). Case study research: Design and methods (5th ed.). Los Angeles, California: Sage Publications

[56] Babbie, E. (1990). Survey Research Methods. Belmont, CA: Wadsworth Publishing

[57] CDC (2001).Word Processing Data base and Statistics Program for Public Health Center for Disease Control and Prevention. Epi Info 6 Version 6.04d.

[58] Nana, C. (2012). Research methods and applied statistics: Beginners and advanced learners. Buea: GOOAHEAD.

Citation: Nengieh Lizzie Wantchami. "Stakeholders' Appraisal of Public Secondary Schools' Communication in the South West Region of Cameroon". International Journal of Media, Journalism and Mass Communications (IJMJMC), vol 4, no. 1, 2018, pp. 27-43. doi:http://dx.doi.org/10. 20431/2455-0043.0401003

Copyright: () 2018 Authors. This is an open-access article distributed under the terms of the Creative Commons Attribution License, which permits unrestricted use, distribution, and reproduction in any medium, provided the original author and source are credited. 